\title{
Inhibition of Glycine-Serine Interconversion in Cultured Human Fibroblasts by Products of Isoleucine Catabolism
}

\author{
RICHARD E. HILLMAN ${ }^{(18)}$ AND ELAINE F. OTTO \\ Washington University School of Medicine and the Division of Medical Genetics, Department of Pediatrics, \\ St. Louis Children's Hospital, St. Louis, Missouri, USA
}

\section{Extract}

Preincubation of fibroblasts with isoleucine before freezethawing inhibited the interconversion of glycine and serine. Inhibition was not seen when isoleucine was added after the cells were broken, which suggests that isoleucine must be metabolized to form an inhibitor substance. Tiglic acid was shown to accumulate during this preincubation period and was demonstrated to inhibit interconversion. Methylene tetrahydrofolate production was also reduced by preincubation with isoleucine or incubation with tiglic acid but this decreased production could not be proven to be related to inhibition of serine-glycine interconversion.

\section{Speculation}

The metabolic consequences of the three enzyme deficiencies associated with the "ketotic hyperglycinemia" syndrome are protean. The data presented in this paper suggest that some of the problems may be related to secondary inhibition of tetrahydrofolate metabolism. Folate therapy may be of some value in the clinical management of patients with this syndrome.

The "ketotic hyperglycinemia" syndrome is a serious disorder which presents in early infancy with profound ketoacidosis, hyperammonemia, neutropenia, thrombocytopenia, hyperglycinemia, and hyperglycinuria. Since its original description by Childs et al. (2), this condition has been the subject of much interesting clinical and biochemical investigation. At least three different enzymatic deficiencies in the metabolic pathway from isoleucine to succinyl-CoA have been described in patients with this syndrome. The sister of Childs' original patient was found to have propionyl-CoA carboxylase deficiency (6). Other patients have been described with methylmalonyl-CoA mutase deficiency (13) and $\beta$-ketothiolase deficiency (3). In addition one or more of the last three products preceding propionate in the isoleucine degradative pathway have been identified in the urine of patients with all three of these defects. Tiglic acid excretion was found to be increased with propionyl-CoA carboxylase deficiency (13) and $\beta$-ketothiolase deficiency (3). Butanone and/or $\alpha$-methylacetoacetate were identified with these enzymatic deficiencies $(3,11)$ and with methylmalonyl-CoA mutase deficiency $(13)$. $\alpha$-Methyl- $\beta$-hydroxybutyrate excretion was increased with $\beta$-ketothiolase deficiency (3).

Although these specific enzymatic deficiencies have been identified, most of the clinically important biochemical changes associated with this condition have not been satisfactorily explained. A recent report from this laboratory (4) demonstrated that glycine oxidation to $\mathrm{CO}_{2}$ was inhibited when cultured fibroblasts from a patient with $\beta$-ketothiolase deficiency were incubated with isoleucine. The studies presented in the present report suggest a possible mechanism of this inhibition.

\section{MATERIALS AND METHODS}

Skin biopsy explants and their subcultures from a patient with $\beta$-ketothiolase deficiency and two age-matched control subjects were grown in nutrient mixture F-12 (16) which contained $12 \mathrm{mM}$ glutamine, $10 \%$ fetal calf serum, $30 \mathrm{mM}$ Tricine, $\mathrm{pH}$ 7.6, penicillin, 100,000 i.u./liter, and streptomycin, $100 \mathrm{mg} /$ liter. Fibrobasts were grown to confluency in Bellco roller bottles $\left(1,410 \mathrm{~cm}^{2}\right)$, harvested with $0.25 \%$ trypsin, washed twice with isotonic saline, and then centrifuged at $500 \times g$ before resuspension in the final reaction mixture.

Interconversion of glycine and serine was measured using radioactive substrates by modification of the procedure of Schirch (14) for the measurement of serine transhydroxymethylase (EC. 2.1.2.1, L-serine:tetrahydrofolate 5,10-hydroxymethyltransferase). Harvested fibroblasts were suspended in Krebs phosphate buffer ( $\mathrm{pH} 7.4$ ) containing pyridoxal $5^{\prime}$-phosphate $12.35 \mathrm{mg} / \mathrm{liter}$, and $\mathrm{NADP}^{+}, 500$ $\mathrm{mg} / \mathrm{liter}$, and incubated for $1 \mathrm{hr}$ at $37^{\circ}$. Five milliliters of cell suspension were mixed with $1 \mathrm{ml} 4 \mathrm{mM}$ tetrahydrofolic acid in $0.2 \mathrm{M}$ mercaptoethanol, freeze-thawed three times, and then pipetted into small test tubes containing either glycine or serine. When the effects of isoleucine on glycine-serine interconversion were studied, either isoleucine was added at the same time as the serine or glycine or the fibroblasts were incubated for $1 \mathrm{hr}$ at $37^{\circ}$ with isoleucine before the addition of tetrahydrofolate and freeze-thawing. Final suspensions contained $0.7-1.1 \mathrm{mg} / \mathrm{ml}$ protein. The $\mathrm{pH}$ of the final solutions was 6.6 .

The effects of $\mathrm{NAD}^{+}$and $\mathrm{NADP}^{+}$on glycine-serine interconversion were compared. At equimolar concentrations, no differences in activity were noted and $\mathrm{NADP}^{+}$was used in all subsequent determinations.

Reaction mixtures consisted of $0.5 \mathrm{ml}$ freeze-thawed suspension and $0.1 \mathrm{ml}$ either glycine or. serine solution. The final concentration of the amino acid to be studied was $1 \mathrm{mM}$ and contained $2.5 \mu \mathrm{Ci}{ }^{14} \mathrm{C} /$ incubation tube. These mixtures were incubated for $3 \mathrm{hr}$ at $37^{\circ}$ in a water bath. Controls included incubation mixtures without freeze-thawed cells 
incubated for $3 \mathrm{hr}$, mixtures with freeze-thawed cells which were processed immediately after the addition of substrates, and freeze-thawed cells incubated without added amino acids.

After completion of the incubation period $30 \mu \mathrm{l}$ each incubation mixture were spotted on $104 \mathrm{~cm}$ long Whatman no. $3 \mathrm{MM}$ paper and electrophoresed for $2 \mathrm{hr}$ at $3,000 \mathrm{~V}$ in a Savant high voltage electrophoresis apparatus $(1.7 \%$ formic acid, $\mathrm{pH}$ 1.9). This procedure provides a $17 \mathrm{~cm}$ separation between glycine and serine. Strips $1.5 \mathrm{~cm}$ in width were cut from the dried chromatograms and counted in a liquid scintillation counter after the addition of a standard scintillation mixture.

Methylene tetrahydrofolate production was measured as methenyltetrahydrofolate using the procedure of Scrimgeour and Huennekens (15). After the incubation period, $0.05 \mathrm{ml} 2$ $\mathrm{N} \mathrm{HCl}$ was added to $0.5 \mathrm{ml}$ incubation mixture. The samples were spun at $12,000 \times g$ in a Sorvall RC2B centrifuge for 10 min and absorbance at $355 \mathrm{~nm}$ was measured in the supernatant fluid. Values were compared with similar samples to which $2 \mathrm{~N} \mathrm{HCl}$ had been added at zero time and results were expressed as the change in absorbance during the 3-hr incubation period.

The effects of increased levels of tetrahydrofolate were studied by increasing the concentration 2.5 -fold (the maximal solubility at $\mathrm{pH}$ 6.6) and by incubating the reaction mixture with preformed methylene tetrahydrofolate. The methylene tetrahydrofolate was prepared by incubating formaldehyde and tetrahydrofolate according to the procedure of Huennekensiet al. (7).

The effects of dialysis on the reaction mixture were studied by dialyzing the fibroblast lysates against Krebs-phosphate buffer containing pyridoxal $5^{\prime}$-phosphate $(12.35 \mathrm{mg} / \mathrm{liter})$ and $\mathrm{NADP}^{+}(500 \mathrm{mg} /$ liter $)$ in an Amicon cell using a PM30 filter. A $1,000 / 1$ dialysis was accomplished. The reactions were then studied as described previously.

The accumulation of tiglic acid by the cells was studied using computer-coupled, multiple ion detection mass spectrometry (5). The cell lysate was extracted and trimethylsilyl derivatives prepared using a modification of the method of Mamer et al. (10). The silyl derivatives of ether-extractable acids were chromatographed on a SE 30 column $\left(40-100^{\circ}\right.$ at $2^{\circ} /$ min) in an LKB 9000 mass chromatograph. The mass ion $\left(\mathrm{M}^{+}\right)$and the mass minus $15\left(\mathrm{M}^{+}-15\right)$ were continuously monitored. Quantitation was accomplished by comparison with standard amounts of tiglic acid run similarly. The extraction procedure may hydrolyze tiglyl-CoA to tiglic acid. One bottle of cells was used in each experiment. One-half of the cells were incubated with and one-half without isoleucine $(10 \mathrm{mM})$ for $1 \mathrm{hr}$ before lysing the cells and extraction.

When tiglic acid was evaluated for inhibitor activity, this compound was added at the same time as the amino acid substrates. The final concentration of tiglic acid in the reaction mixture was $1 \mathrm{mM}$. Protein was measured by a modified Lowry procedure (7). Radioactive substrates, $\left(1{ }^{14} \mathrm{C}\right)$ gly cine, $\left(2-{ }^{14} \mathrm{C}\right)$ glycine, and $\left(U_{-}{ }^{14} \mathrm{C}\right) \mathrm{L}$-serine, were obtained from New England Nuclear Corporation. Glycine, L-serine, L-isoleucine, tiglic acid, pyridoxal $5^{\prime}$-phosphate, $\mathrm{NADP}^{+}, \mathrm{NAD}^{+}$, and tetrahydrofolate were obtained from Sigma. Other chemicals were obtained from Fisher.

\section{RESULTS}

The time course of glycine production from serine, serine production from glycine, and methylene tetrahydrofolate production during both reactions were studied over a 4-hr time period. Using the techniques described, no activity was consistently detectable when measured as serine or glycine production until the solutions had incubated for $0.5-1 \mathrm{hr}$. Thereafter, measurable production of serine or glycine increased linearly until the 3 -hr time point. After $3 \mathrm{hr}$ incubation, the activity decreased. Methylene tetrahydrofolate production was measurable as early as $15 \mathrm{~min}$ after the beginning of the incubation period and its absolute increase paralleled the production of serine or glycine. Because all measurements were most easily duplicated at $3 \mathrm{hr}$ of incubation, this time point was chosen for further studies.

Serine production from glycine and glycine production from serine were linear with respect to protein from protein concentrations of $0.6-1.3 \mathrm{mg} / \mathrm{ml}$. At protein concentrations less than $0.6 \mathrm{mg} / \mathrm{ml}$ there was a relative decrease in interconversion.

The rate of serine production from glycine was fairly constant from culture bottle to culture bottle. However, glycine production from serine was more variable. Therefore, all experiments were performed using cells from a single roller bottle culture.

As shown in Table 1, production of serine from both $\left(1-{ }^{14} \mathrm{C}\right)$ glycine and $\left(2-{ }^{14} \mathrm{C}\right)$ glycine and production of glycine from serine were inhibited by preincubation of the cells with $10 \mathrm{mM}$ isoleucine. No inhibition was noted when isoleucine was added simultaneously with glycine or serine after the cells were broken. Inhibition occurred in both normal cell lines and in the patient's cells. However, the degree of inhibition was much greater for the patient's cells for all three substrates, about $60 \%$ as compared with about $30 \%$ for the control cell lines. Glycine conversion to serine was significantly less in the patient's cells than the control cells even in the absence of isoleucine. When $1 \mathrm{mM}$ isoleucine was added to the preincubation mixture, $25 \%$ inhibition occurred in the patient's cells but no inhibition occurred in the control cell lines.

When the cell lysates were dialyzed before incubation studies, glycine conversion to serine in the patient's cells increased to near normal levels (Table 2). The conversion of serine to glycine increased in both the normal and the patient's cells.

Tiglic acid was measured in control and patient cells after 1 -hr incubations with and without $10 \mathrm{mM}$ isoleucine (Table 3 ). The other two products of isoleucine metabolism prior to the proposed block in this patient, $\alpha$-methyl- $\beta$-hydroxybutyric acid and $\alpha$-methylacetoacetic acid, could not be measured by

\section{Table 1. Glycine-serine interconversion in fibroblast lysates ${ }^{1}$}

\begin{tabular}{|c|c|c|c|}
\hline \multirow[b]{2}{*}{ Substrate } & \multicolumn{3}{|c|}{$\begin{array}{l}\text { Serine or glycine produced, } \\
\text { mol } \times 10^{9} / \mathrm{mg} \text { protein }\end{array}$} \\
\hline & $\begin{array}{c}\text { Substrate } \\
\text { only }\end{array}$ & $\begin{array}{c}\text { Substrate } \\
+10 \mathrm{mM} \\
\text { isoleucine }\end{array}$ & Inhibition, $\%$ \\
\hline \multicolumn{4}{|l|}{ Control cells } \\
\hline$\left(11^{14} \mathrm{C}\right)$ Glycine & $2.97 \pm 0.12$ & $2.07 \pm 0.02$ & 30.3 \\
\hline$\left(2-^{-14} \mathrm{C}\right)$ Glycine & $3.65 \pm 0.20$ & $2.33 \pm 0.04$ & 36.1 \\
\hline$\left(U-{ }^{14} \mathrm{C}\right)$ Serine & $14.33 \pm 0.38$ & $9.83 \pm 10.23$ & 31.4 \\
\hline \multicolumn{4}{|l|}{ Patient's cells } \\
\hline$\left(11^{14} \mathrm{C}\right)$ Glycine & $2.38 \pm 0.10$ & $1.07 \pm 0.03$ & 55.2 \\
\hline$\left(2-^{14} \mathrm{C}\right)$ Gly cine & $2.38 \pm 0.05$ & $0.85 \pm 0.05$ & 64.3 \\
\hline$\left(U-^{14} \mathrm{C}\right)$ Serine & $18.65 \pm 0.77$ & $8.82 \pm 0.72$ & 52.7 \\
\hline
\end{tabular}

${ }^{1}$ Cell lysates from normal subjects and a patient with $\beta$-ketothiolase deficiency were incubated for $3 \mathrm{hr}$ with $1 \mathrm{mM}$ solutions of glycine or serine. The reaction mixture contained pyridoxal phosphate, 12:35 $\mathrm{mg} / \mathrm{liter}$, and NADP+, $500 \mathrm{mg} / \mathrm{liter}$. Tetrahydrofolate was added just before beginning the incubation. Radioactivity traveling with authentic glycine and serine was measured after high voltage electrophoresis. To study the effects of isoleucine, cells were preincubated for $1 \mathrm{hr}$ with 10 $\mathrm{mM}$ isoleucine before freeze-thawing and the addition of substrate. Results represent the mean and SE of 8-12 separate measurements, done in two separate experiments using cells grown for the same length of time in culture. Cells from the same culture bottle were used for incubation with and without isoleucine. 
Table 2. Glycine-serine conversion in dialyzed fibroblast lysates ${ }^{1}$

\begin{tabular}{crrr}
\hline & \multicolumn{3}{c}{$\begin{array}{c}\text { Serine or glycine produced, } \\
\mathrm{mol} \times 10^{9} / \mathrm{mg} \text { protein }\end{array}$} \\
\cline { 2 - 4 } Substrate & \multicolumn{1}{c}{ Undialyzed } & \multicolumn{1}{c}{ Dialyzed } & Change, \% \\
\hline Control cells & & & \\
$\left(U-{ }^{14} \mathrm{C}\right)$ Glycine & $3.14 \pm 0.14$ & $3.62 \pm 0.02$ & +15.3 \\
$\left(U-{ }^{14} \mathrm{C}\right)$ Serine & $20.52 \pm 0.44$ & $32.72 \pm 0.32$ & +59.4 \\
Patient's cells & & & \\
$\left(U-{ }^{14} \mathrm{C}\right)$ Glycine & $1.50 \pm 0.02$ & $2.63 \pm 0.14$ & +75.3 \\
$\left(U-{ }^{14} \mathrm{C}\right)$ Serine & $17.94 \pm 3.76$ & $31.35 \pm 1.05$ & +74.7 \\
\hline
\end{tabular}

${ }^{1}$ Cell lysates were dialyzed 1000/1 using an Amicon cell with a PM30 filter against the same buffer used in the reaction mixture prior to the addition of substrate and tetrahydrofolate. Studies then proceeded as in Table 1 .

Table 3. Tiglic acid content of cultured fibroblasts ${ }^{1}$

\begin{tabular}{lcrr}
\hline & \multicolumn{3}{c}{ Tiglic acid, ng/mg protein (mM) } \\
\cline { 2 - 4 } & Buffer only (a) & $\begin{array}{c}\text { Buffer } \\
+10 \mathrm{mM} \\
\text { isoleucine (b) }\end{array}$ & $\mathrm{b} / \mathrm{a}$ \\
\hline Patient's cells & $2.64(0.006)$ & $39.60(0.091)$ & 15.0 \\
Control subject 1 & $9.64(0.022)$ & $15.62(0.036)$ & 1.6 \\
Control subject 2 & $3.96(0.009)$ & $5.36(0.012)$ & 1.4 \\
\hline
\end{tabular}

${ }^{1}$ Cells were incubated for $1 \mathrm{hr}$ with or without $10 \mathrm{mM}$ isoleucine. After lysing the cells, tiglic acid was measured using computer-controlled, multiple ion detection mass spectrometry. See text for details.

this technique. The tiglic acid concentration in the cells increased 15-fold in the patient's cells and 1.6-fold in one control cell line and 1.4-fold in the other. Using the published data for the relation of cell water to cell protein (9), the final concentration of tiglic acid in the patient's cells was $0.09 \mathrm{mM}$.

The effect of tiglic acid on control cell lysates was studied (Table 4). Tiglic acid ( $1 \mathrm{mM})$ added at the same time as glycine or serine inhibited both glycine conversion to serine and serine conversion to glycine. The inhibition was similar to that seen when control cells were incubated with isoleucine $(10 \mathrm{mM})$. These data and the measured concentrations of tiglic acid suggest that tiglic acid must be converted to tiglyl-CoA to act as an inhibitor of these reactions.

To further define the inhibitory action of isoleucine and tiglic acid on serine-glycine interconversion, the production of methylene tetrahydrofolate was measured (Table 5). Methylene tetrahydrofolate production paralleled the production of serine or glycine. Production was less in the patient's cells than in the control cells. Production was inhibited by preincubation with isoleucine or incubation with tiglic acid and could be increased toward normal in the patient's cells by dialysis. However, production of methylene tetrahydrofolate was about the same in cells incubated without added amino acids as in cells incubated in the presence of glycine or serine. Therefore, it was concluded that the measured production of methylene tetrahydrofolate was not produced primarily by glycine-serine interconversion and that the inhibitory action affected more than just that reaction. The production of methylene tetrahydrofolate was somewhat greater during serine conversion to glycine than in the no amino acid control and somewhat less during glycine conversion to serine, which suggested that some methylene tetrahydrofolate is produced in the first reaction and some used in the second.

To further investigate this process, the effects of increasing the concentration of tetrahydrofolate in the reaction mixture and substituting methylene tetrahydrofolate for tetrahydrofolate were investigated in the patient's cells (Table 6). Increasing the concentration of tetrahydrofolate from 0.7 to $1.75 \mathrm{mM}$ altered both glycine-serine interconversion and inhibition of this interconversion by isoleucine. The absolute amount of glycine produced from serine was increased by the increased concentration of tetrahydrofolate, which suggested that saturating concentrations of this compound for this reaction had not been reached or that the compound was unstable during the incubation period. Thus, although isoleucine still inhibited glycine production by $49 \%$ in the presence of $1.75 \mathrm{mM}$ tetrahydrofolate, the amount of glycine produced under these conditions was about the same as that produced in lysates not preincubated with isoleucine in the presence of $0.7 \mathrm{mM}$ tetrahydrofolate. Increasing the concentration of tetrahydrofolate did not stimulate serine production from $\left(1-{ }^{14} \mathrm{C}\right)$ glycine. However, inhibition by isoleucine was reduced from $55 \%$ to $39 \%$.

When $0.7 \mathrm{mM}$ methylene tetrahydrofolate was substituted for $0.7 \mathrm{mM}$ tetrahydrofolate, $\left(1-{ }^{14} \mathrm{C}\right)$ glycine conversion to serine was increased more than twofold whether or not isoleucine was present in the incubation mixture, and preincubation with isoleucine inhibited this reaction by only $15 \%$. As expected, serine conversion to glycine was decreased by this substitution because less free tetrahydrofolate was available as a methyl receptor. Under these conditions, this conversion was inhibited only $26 \%$ by isoleucine. The absolute amount of glycine produced from serine after preincubation with isoleucine was the same with either cofactor.

\section{DISCUSSION}

Glycine oxidation to $\mathrm{CO}_{2}$ was shown previously to be reduced when fibroblasts grown from a patient with $\beta$-ketothiolase deficiency were preincubated with isoleucine (4). Most glycine oxidation probably occurs during or after conversion to serine. The data presented in this paper suggest that preincubation of fibroblasts with isoleucine or incubation of fibroblasts with tiglic acid inhibits glycine oxidation by inhibiting the conversion of glycine to serine.

Although both serine conversion to glycine and glycine conversion to serine were inhibited, quantitative differences could be seen in the data. Without preincubation with isoleucine, about $19 \times 10^{-9} \mathrm{~mol}$ glycine were produced from serine and $2.5 \times 10^{-9} \mathrm{~mol}$ serine were produced from glycine. After preincubation with isoleucine, $9 \times 10^{-9}$ mol glycine were still produced but only $1 \times 10^{-9} \mathrm{~mol}$ serine. Thus, although it is difficult to interpret the clinical hyperglycinemia seen in this patient directly on the basis of these experimental data, the data do suggest that quantitative conversion of serine to glycine may be sufficiently active in the face of limited conversion of glycine to serine to produce elevated glycine levels.

Table 4. Inhibition of serine-glycine interconversion in cell lysates from normal individuals ${ }^{1}$

\begin{tabular}{|c|c|c|c|}
\hline \multirow[b]{2}{*}{ Substrate } & \multicolumn{3}{|c|}{$\begin{array}{l}\text { Glycine or serine produced, } \\
\text { mol } \times 10^{9} / \mathrm{mg} \text { protein }\end{array}$} \\
\hline & $\begin{array}{l}\text { Substrate } \\
\text { only }\end{array}$ & $\begin{array}{c}\text { Substrate }+ \\
\text { tiglate } \\
(1 \mathrm{mM})\end{array}$ & Inhibition, $\%$ \\
\hline$\left(11^{14} \mathrm{C}\right)$ Glycine & $2.34 \pm 0.14$ & $1.86 \pm 0.05$ & 20.6 \\
\hline$\left(U-{ }^{14} \mathrm{C}\right)$ Serine & $28.3 \pm 4.2$ & $16.6 \pm 0.9$ & 44.3 \\
\hline
\end{tabular}

${ }^{1}$ The reaction conditions were listed in Table 1. Tiglic acid was added at the same time as the substrate. 
Table 5. Methylene tetrahydrofolate production during glycine-serine interconversion ${ }^{1}$

\begin{tabular}{lcccc} 
& & \multicolumn{2}{c}{$\Delta$ Absorption at $355 \mathrm{~nm}$} & \\
\cline { 3 - 4 } \multicolumn{1}{c}{ Substrate } & $\begin{array}{c}\text { Substrate } \\
\text { only }\end{array}$ & $\begin{array}{c}\text { Dialyzed } \\
\text { lysate }\end{array}$ & $\begin{array}{c}\text { Substrate } \\
\text { + isoleucine }(10 \mathrm{mM})\end{array}$ & $\begin{array}{c}\text { Substrate } \\
+ \text { tiglate }(1 \mathrm{mM})\end{array}$ \\
\hline $\begin{array}{l}\text { Control subjects' cells } \\
\text { Glycine }\end{array}$ & & & & $0.469 \pm 0.013$ \\
$\quad$ Serine & $0.588 \pm 0.026$ & $0.619 \pm 0.013$ & $0.475 \pm 0.015$ & $0.341 \pm 0.071$ \\
$\quad$ None & $0.614 \pm 0.010$ & $0.791 \pm 0.025$ & $0.478 \pm 0.038$ & \\
Patient's cells & $0.601 \pm 0.010$ & $0.676 \pm 0.031$ & & \\
$\quad$ Glycine & $0.182 \pm 0.020$ & $0.318 \pm 0.017$ & $0.034 \pm 0.017$ & \\
$\quad$ Serine & $0.289 \pm 0.015$ & $0.518 \pm 0.024$ & $0.054 \pm 0.018$ & \\
$\quad$ None & $0.236 \pm 0.020$ & $0.422 \pm 0.009$ & & \\
\hline
\end{tabular}

${ }^{1}$ Cell lysates were incubated for $3 \mathrm{hr}$ as in Table 1 . After incubation $0.5 \mathrm{ml}$ lysate was mixed with $0.05 \mathrm{ml} 2 \mathrm{~N}$ HCl. The mixtures were spun at $12,000 \times \mathrm{g}$ for $10 \mathrm{~min}$ and then absorbance at $355 \mathrm{~nm}$ was measured. Results represent the different between absorption at zero time and at $3 \mathrm{hr}$. Numbers represent the mean and SE of 8-12 measurements. Substrate only values differed somewhat from experiment to experiment. To simplify data presentation, values from experiments using dialyzed cells and experiments where tiglic acid was used as an inhibitor were normalized to the same substrate only value as the isoleucine inhibition experiment.

Table 6. Effects of increased tetrahydrofolate (THF) concentrations and methylene tetrahydrofolate (MeTHF) on glycine-serine interconversion and inhibition (Inhib.) of interconversion by isoleucine ${ }^{1}$

\begin{tabular}{|c|c|c|c|c|c|c|}
\hline & \multicolumn{6}{|c|}{ Glycine or serine produced $/ \mathrm{mol} \times 10^{9} / \mathrm{mg}$ protein } \\
\hline & $0.7 \mathrm{mM} \mathrm{THF}$ & Inhib., \% & $1.75 \mathrm{mM} \mathrm{THF}$ & Inhib., \% & $0.7 \mathrm{mM} \mathrm{MeTHF}$ & Inhib., \% \\
\hline \multicolumn{7}{|l|}{ Substrate only } \\
\hline$\left(1-^{14} \mathrm{C}\right)$ Glycine & $2.38 \pm 0.10$ & & $2.28 \pm 0.05$ & & $5.92 \pm 1.03$ & \\
\hline$\left(U-{ }^{14} \mathrm{C}\right)$ Serine & $18.65 \pm 0.77$ & & $31.25 \pm 0.88$ & & $11.37 \pm 0.63$ & \\
\hline \multicolumn{7}{|c|}{ Substrate $+10 \mathrm{mM}$ isoleucine } \\
\hline$\left(11^{14} \mathrm{C}\right)$ Glycine & $1.07 \pm 0.03$ & 55.2 & $1.38 \pm 0.27$ & 39.4 & $5.02 \pm 0.25$ & 15.1 \\
\hline$\left(U_{-}{ }^{4} \mathrm{C}\right)$ Serine & $8.82 \pm 0.77$ & 52.7 & $15.47 \pm 0.10$ & 48.8 & $8.37 \pm 0.62$ & 26.1 \\
\hline
\end{tabular}

${ }^{1}$ Fibroblasts grown from patient's cells were incubated as in Table 1 with the exception that either $1.75 \mathrm{mM}$ THF or $0.7 \mathrm{mM}$ THF which had been preincubated with formaldehyde to form MeTHF was substituted for $0.7 \mathrm{mM}$ THF.

The activity of the enzyme serine transhydroxymethylase is several fold greater with serine rather than glycine as substrate. The studies in the patient's cells further suggest that the conversion of glycine to serine is more sensitive to the inhibition or inhibitors present in cells grown from a patient with $\beta$-ketothiolase deficiency than in the reverse reaction. Glycine conversion was reduced in the patient's cells but returned toward normal when the cell lysates were dialyzed. Serine conversion to glycine in the absence of added inhibitors was quite similar to the control cell lines.

The role of tetrahydrofolate in this inhibition is not clear from the studies presented. Although production of methylene tetrahydrofolate is inhibited, this decrease in production cannot be specifically demonstrated to be caused by inhibition of serine transhydroxymethylase. The data suggest that the production of methylene tetrahydrofolate by other reactions may also be inhibited.

However, if tetrahydrofolate is related to the inhibition, then these findings could be interpreted in light of the studies of serine transhydroxymethylase (1) by Chen and Schirch. These workers concluded that formaldehyde is transferred from serine to 5,10-methylene tetrahydrofolate through an intermediate enzyme-formaldehyde complex. They propose that serine first forms a Schiff base complex with the enzyme which is cleaved to an enzyme-formaldehyde-glycine complex. Formaldehyde then dissociates either directly or much more rapidly by its interaction with tetrahydrofolate. Our data could thus be interpreted as demonstrating that enzymeformaldehyde-glycine complex is formed normally, but the rate-limiting interaction with tetrahydrofolate is inhibited.

\section{SUMMARY}

The interconversion of glycine and serine was studied in fibroblasts cultured from normal individuals and from a patient with ketotic hyperglycinemia syndrome. Interconversion was reduced by preincubating the cells with isoleucine or incubating the broken cell extracts with tiglic acid. Inhibition was much greater in the patient's cells. Tiglic acid was shown to accumulate in the cells during the preincubation with isoleucine. Methylene tetrahydrofolate production was also reduced by preincubation with isoleucine or incubation with tiglic acid. Serine production from glycine was reduced in the patient's cells even in the absence of added isoleucine and was shown to return toward normal when the cell extracts were dialyzed before the interconversion studies.

\section{REFERENCES AND NOTES}

1. Chen, M. S., and Schirch, L.: Serine transhydroxymethylase. J. Biol. Chem., 248: 3631 (1973).

2. Childs, B., Nyhan, W. L., Borden, M., Bard, L., and Cooke, R. E.: Idiopathic hypergly cinemia and hyperglycinuria: A new disorder of amino acid metabolism. Pediatrics, 27: 522 (1961).

3. Hillman, R. E., and Keating, J. P.: Beta-ketothiolase deficiency as a cause of the ketotic hyperglycinemia syndrome. Pediatrics, 53: 221 (1974).

4. Hillman, R. E., Sowers, L. H., and Cohen, J. L.: Inhibition of glycine oxidation in cultured fibroblasts by isoleucine..Pediat. Res., 7: 945 (1973).

5. Holmes, W. F., Holland, W. H., Shore, B. L., Bier, D. M., and Sherman, W. R.: A versatile computer generated variable accelerating voltage circuit for magnetically scanned mass spectrometers: Use for assays in the picogram range and for 
assays of stable isotope tracers. Anal. Chem., 45: 2063 (1973).

6. Hsia, Y. E., Scully, K. J., and Rosenberg, L. E.: Defective propionate carboxylation in ketotic hyperglycinemia. Lancet, $i$ : 757 (1969).

7. Huennekens, F. M., Ho, P. P. K., and Scrimgeour, K. G.: Preparation and properties of "active formaldehyde" and "active formate." Methods Enzymol., 6: 806 (1963).

8. Lowry, O. H., Rosebrough, N. J., Farr, A. L., and Randall, R. J.: Protein measurement with the Folin phenol reagent. J. Biol. Chem., 193: 265 (1951).

9. Mahoney, M. J., and Rosenberg, L. E.: Uptake of $\alpha$-amino isobutyric acid by cultured human fibroblasts. Biochim. Biophys. Acta, 219: 500 (1970).

10. Mamer, O. A., Crawhall, J. C., and Tjoa, S. S.: The identification of urinary acids by coupled gas chromatography-mass spectrometry. Clin. Chim. Acta, 32: 171 (1971).

11. Menkes, J. H.: Idiopathic hyperglycinemia: Isolation and identification of three previously undescribed urinary ketones. J. Pediat., 69: 413 (1966).

12. Nyhan, W. L., Ando, T., Rasmussen, K., Wadlington, W., Kilroy, A. W., Cottom, D., and Hull, D.: Tiglicaciduria in propionicacid-

Copyright (C) 1974 International Pediatric Research Foundation, Inc. aemia. Biochem. J., 126: 1035 (1972)

13. Rosenber , F , Lilljeqvist, A. C., and Hsia, Y. E.: Methylmalonic acidemia: An inborn error leading to metabolic acidosis, long chain ketonuria and intermittent hy perglycinemia. New Engl. J. Med., 278: 1319 (1968).

14. Schirch, L.: Serine transhydroxymethylase. Methods Enzymol., 17: 335 (1971).

15. Scrimgeour, K. G., and Huennekens, F. M.: N5, N10-Methylene tetrahydrofolic dehydrogenase. Methods Enzymol., 6: 368 (1963).

16. Grand Island Biological Co., Chagrin Falls, Ohio.

7. This work was supported in part by United States Public Health
Service Grant no. AM 15531 and the Ranken Jordan Trust Fund. Service Grant no. AM 15531 and the Ranken Jordan Trust Fund.
The authors wish to thank Mrs. Liang Chu Daniel for her technical assistance and Mrs. Sabra Lovejoy for her aid in preparing this manuscript.

18. Requests for reprints should be addressed to: R. E. Hillman, M.D., Division of Medical Genetics, Department of Pediatrics, St. Louis Children's Hospital, 500 S. Kingshighway, St. Louis, Mo. 63110 (USA).

19. Accepted for publication July 15, 1974.

Printed in U.S.A.

Pediat. Res. 8: 945-950 (1974)

Adenosine arabinoside brain congenital disease cytosine arabinoside retina

\title{
Effect of the Antiviral Drug, Cytosine Arabinoside, on the Developing Nervous System
}

\author{
STEPHEN ASHWAL, MILTON FINEGOLD, IRVING FISH, GLEB BUDZILOVICH, AND \\ PHILIP A. BRUNELL ${ }^{(17)}$ \\ Departments of Pediatrics, Pathology, and Neurology, New York University School of Medicine, \\ New York, New York, USA
}

\section{Extract}

Cytosine arabinoside (which is used to treat congenital viral infections) produced neurologic and retinal damage in infant mice. Station and gait abnormalities could be related to hypoplasia and marked microscopic changes in the cerebellum of treated animals. These, as well as microscopic changes in the retina, appeared to be irreversible. The damage produced appeared to result from destruction of primordial cells during a critical period of differentiation.

\section{Speculation}

The potential for producing neurologic and other damage by treatment with DNA inhibitors during this period of rapid growth must be considered when contemplating the use of these DNA inhibitors for treatment of congenital virus infections.

The treatment of newborn infants suffering from congenital virus infections with inhibitors of DNA synthesis has been reported $(2,4,7,8,10)$. Therapy has been based on the observations that such compounds as iododexoxyuridine, adenosine arabinoside (Ara-A), or cytosine arabinoside (Ara-C) inhibit these DNA viruses in vitro (12). In vivo, however, these compounds may restrict host DNA synthesis in uninfected as well as in virus-infected cells. This is of particular concern in newborn infants whose cells are undergoing active division and differentiation.

The potential effect of DNA inhibitors on the developing central nervous system (CNS) of the neonate is of particular concern because of the devastating consequences that might ensue if functions were permanently impaired. It has been shown, moreover, that cellular growth and differentiation continues after birth in the human $(5,13)$. Ara-C, which has been used to treat infants with congenital viral infections, was found to have a deleterious effect on both function and structure of the mouse nervous system. The implication of these observations for treatment of newborn infants with congenital viral infections with DNA inhibitors is considered in this light.

\section{METHODS}

Experiments were carried out using 57 litters each consisting of 8 newborn CFW (14) mice. Members of a single mouse litter were injected subcutaneously with $0.03 \mathrm{cc}$ of either normal saline or Ara-C (15). The drug was administered in single doses of $50 \mathrm{mg} / \mathrm{kg}$ which were given on 3 alternate days beginning on the 2nd day of life. Mice were observed for neurologic or 